\title{
Gender Sebagai Pemoderasi Pengaruh Orientasi Tujuan dan Self-Efficacy pada Audit Judgment
}

\author{
I Gusti Agung Rama Sidhimantra ${ }^{1}$ \\ Fakultas Ekonomi dan Bisnis \\ Universitas Udayana, Indonesia
}

\author{
Ida Bagus Putra Astika ${ }^{2}$ \\ Fakultas Ekonomi dan Bisnis \\ Universitas Udayana, Indonesia
}

Surel : ramasidhimantra95@gmail.com

ABSTRAK

Hasil penelitian orientasi tujuan dan self-efficacy pada audit judgment ditemukan ketidakkonsistenan yang diduga karena ada faktor lain yang mempengaruhi hubungan antara variabel bebas dengan variabel terikat. Variabel gender sebagai variabel moderasi diharapkan dapat menjelaskan ketidakkonsistenan tersebut. Penelitian ini bertujuan menguji gender memoderasi pengaruh orientasi tujuan dan self-efficacy pada audit judgment. Populasi dari penelitian ini adalah seluruh auditor yang bekerja pada KAP di wilayah Bali yang terdaftar dalam Ikatan Akuntan Publik Indonesia 2020 sebanyak 110 orang. Metode penentuan sampel yaitu metode non probability sampling dengan teknik purposive sampling, sedangkan metode pengumpulan data menggunakan metode survei dengan teknik kuesioner. Teknik analisis yang digunakan adalah regresi moderasi. Hasil penelitian menunjukan orientasi tujuan dan self-efficacy berpengaruh positif pada audit judgment. Gender memperkuat pengaruh orientasi tujuan pada audit judgment sedangkan gender memperlemah pengaruh selfefficacy pada audit judgment. Kata Kunci: Orientasi Tujuan; Self-Efficacy; Gender; Audit Judgment. E-Jurnal Akuntansi, Judgment.

\section{Gender Moderate Relationship Between Goals Orientation and Self-Efficacy in Audit judgment}

\begin{abstract}
The results of the study of goal orientation and self-efficacy on audit judgment found inconsistencies that are suspected because there are other factors that influence the relationship between the independent variable and the dependent variable. The gender variable as a moderating variable is expected to explain the inconsistency. This study aims to test gender to moderate the effect of goal orientation and self-efficacy on audit judgment. The population of this study were all auditors who worked at public accountant office in the Bali region who were registered in Indonesian Institute of Public Accountant 2020 as many as 110 people. The method of determining the sample is non-probability sampling method with purposive sampling technique, while the method of data collection uses survey method with questionnaire technique. The analysis technique used is moderated regression analysis. The results showed that goal orientation and selfefficacy had a positive effect on audit judgment. Gender strengthens the effect of goal orientation on audit judgment while Gender weakens the effect of self-efficacy on audit judgment.
\end{abstract}

Keywords: Goal Orientation; Self-Efficacy; Gender; Audit Judgment.

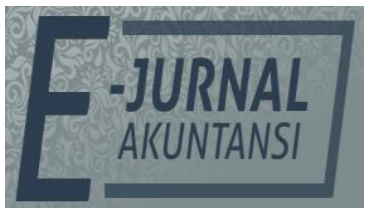

e-ISSN 2302-8556

Vol. 31 No. 10

Denpasar, Oktober 2021

Hal. 2429-2441

DOI:

10.24843/EJA.2021.v31.i10.p02

PENGUTIPAN:

Sidhimantra, I.G.A.R., \& Astika, I.B.P. (2021). Gender

Sebagai Pemoderasi dan Self-Efficacy pada Audit 31(10), 2429-2441

RIWAYAT ARTIKEL: Artikel Masuk: 21 Desember 2021 Artikel Diterima: 4 Maret 2021
Pengaruh Orientasi Tujuan

Artikel dapat diakses : https://ojs.unud.ac.id/index.php/Akuntansi/index 


\section{PENDAHULUAN}

Persaingan yang semakin ketat diantara para pelaku bisnis menyebabkan para pengelola usaha melakukan berbagai macam usaha untuk meningkatkan pendapatan agar dapat bertahan dalam menghadapi persaingan (Candraningrat et al., 2021). Perusahaan wajib menyajikan laporan keuangan dan melakukan pemeriksaan laporan keuangan oleh pihak ketiga yang independen, dalam hal ini akuntan publik. Perusahaan memerlukan jasa pihak ketiga agar pertanggungjawaban laporan keuangan yang disajikan kepada pihak luar dapat dipercaya.

Sehubungan dengan posisi tersebut, maka keberadaan dan fungsi profesi akuntan publik menunjukan peningkatan seiring dengan ketatnya persaingan dunia usaha dan kesadaran masyarakat akan pentingnya jasa akuntan. Terjadinya kasus kegagalan audit belakangan ini telah menimbulkan krisis kepercayaan masyarakat mengenai profesi akuntan publik tidak mampu dalam mengaudit laporan keuangan. Seperti kasus Enron yang melibatkan KAP Arthur Andersen di Amerika Serikat. Manajemen Enron telah melakukan window dressing, dengan memanipulasi angka-angka laporan keuangan agar kinerjanya tampak baik. Auditor Enron, Arthur Andersen dipersalahkan karena ikut membantu proses rekayasa keuangan itu. Kasus serupa terjadi di Indonesia yaitu PT. Kimia Farma Tbk yaitu manajemen Kimia Farma melaporkan adanya laba bersih sebesar Rp 132 milyar padahal perusahaan seharusnya memperoleh laba sebesar Rp 99 miliar. Telah ditemukannya kesalahan yang cukup mendasar berupa overstated penjualan.

Berbagai kasus yang telah terjadi tersebut berdampak pada krisis kepercayaan investor terhadap auditor. Salah satu penyebabnya adalah kurang tepatnya auditor dalam membuat audit judgment. Pembuatan audit judgment yang kurang tepat akan berpengaruh terhadap kualitas audit (Ariyanto et al., 2020). Melihat pentingnya profesi akuntan maka sewajarnya pula akuntan menuntut adanya kemampuan dalam memproses informasi untuk menentukan audit judgment pada sebuah penugasan audit.

Auditor mengumpulkan bukti dalam waktu yang berbeda dan mengintegrasikan informasi dari bukti tersebut untuk membuat suatu audit judgment. Audit judgment merupakan suatu pertimbangan pribadi atau cara pandang auditor dalam menanggapi informasi yang memengaruhi dokumentasi bukti serta pembuatan keputusan pendapat auditor atas laporan keuangan suatu entitas (Praditaningrum \& Januarti, 2012). Audit judgment akan melekat pada setiap tahap dalam proses audit laporan keuangan, yaitu penerimaan perikatan audit, perencanaan audit, pelaksanaan pengujian audit dan pelaporan audit (Nugraha, 2014). Setiap tahapannya auditor perlu mempertimbangkan materialitas, risiko dan judgment (Darlis et al., 2014) Pembuatan judgment ini auditor mempunyai kesadaran bahwa suatu pertanggungjawaban merupakan faktor yang cukup penting karena penilaiannya akan ditinjau dan dimintai keterangan (Ariyantini et al., 2014)

Audit judgment memainkan peran penting dalam pembentukan pendapat audit (Iskandar \& Sanusi, 2011). Jika seorang auditor melakukan judgment yang kurang tepat akan berpengaruh terhadap ketepatan opini akhir mengenai kewajaran laporan keuangan (Puspitasari, 2011). Penelitian oleh Wijayatri (2010) 
mengungkapkan terdapat pengaruh yang signifikan antara ketepatan judgment yang dikeluarkan seorang auditor dengan kesimpulan akhir yang dihasilkannya. Sehingga seberapa baik kinerja seorang auditor dalam melaksanakan tugasnya ditentukan oleh kualitas judgment seorang auditor.

Banyak faktor yang mempengaruhi kemampuan auditor dalam pembuatan audit judgment. Aspek perilaku individu merupakan faktor teknis yang memengaruhi persepsi auditor dalam menerima dan mengelola informasi yang meliputi faktor pengetahuan, pengalaman, tekanan ketaatan, serta kompleksitas tugas (Irwanti, 2011). Gender merupakan faktor nonteknis yang memengaruhi judgment auditor (Chung \& Monroe, 2001). Beberapa hasil penelitian dalam bidang audit menunjukkan bahwa perilaku individual adalah salah satu faktor yang memengaruhi pembuatan judgment dalam melaksanakan review selama proses audit (Praditaningrum \& Januarti, 2012). Aspek perilaku individual auditor yang akan menjadi variabel dalam penelitian ini meliputi orientasi tujuan dan selfefficacy.

Orientasi tujuan merupakan salah satu faktor penting yang memengaruhi audit judgment. Audit judgment yang baik akan lebih baik dihasilkan oleh auditor yang memilih pekerjaan dengan tugas yang menantang sehingga dapat belajar banyak dan mendapat pengalaman lebih (Pertiwi et al., 2015). Auditor dapat mengakuisisi pengalaman baru tersebut dengan pengalamannya yang sudah ada untuk bekerja dengan baik dalam pengambilan audit judgment yang disesuaikan dengan opini dan fakta yang ada dan standar akuntansi yang berlaku umum (Trianevant, 2014).

Penelitian yang dilakukan Trianevant (2014) menunjukkan orientasi tujuan berpengaruh positif terhadap audit judgment auditor independen, hasil penelitian tersebut juga didukung oleh penelitian Pertiwi et al. (2015) meneliti pengaruh orientasi tujuan terhadap audit judgment. Hasil penelitiannya adalah orientasi tujuan berpengaruh positif terhadap audit judgment. Orientasi tujuan yang tinggi berfokus pada pengembangan kompetensi mereka dengan mengakuisisi keterampilan baru dan belajar dari pengalaman yang digunakan dalam menentukan suatu judgment (Pertiwi et al., 2015). Sebaliknya penelitian yang dilakukan oleh Nadhiroh (2010) menunjukkan orientasi tujuan pembelajaran tidak berpengaruh secara signifikan terhadap audit judgment, hal tersebut disebabkan kinerja auditor dalam pembuatan audit judgment lebih dipengaruhi oleh penguasaan pada tugas yang diberikan, sehingga orientasi tujuan yang dimiliki auditor tidak berpengaruh terhadap kinerja mereka.

Auditor juga harus memiliki kemampuan diri dalam pengambilan audit judgment dalam hal ini ialah self-efficacy. Self-efficacy diturunkan dari teori kognitif sosial, hal tersebut dikemukakan oleh Bandura (1993) yang menyatakan kinerja individu dipengaruhi tidak hanya oleh faktor lingkungan tetapi juga oleh faktor motivasi (yaitu, personal self-efficacy). Self-efficacy merupakan kepercayaan ataupun keyakinan seseorang mengenai kemampuan dirinya untuk melakukan atau menghasilkan sesuatu (Trianevant, 2014).

Self-efficacy diduga turut memengaruhi audit judgment, dikarenakan dengan self-efficacy yang tinggi, auditor dapat mengerjakan tugas yang sederhana maupun yang rumit tanpa ada rasa ragu untuk mengeluarkan judgment. Selain itu auditor yang memiliki self-efficacy yang tinggi dengan yakin dan percaya dapat 
menyelesaikan tugas yang diberikan dan menjalankan tugas audit dengan sebaikbaiknya (Trianevant, 2014). Pada penelitian (Wijayantini et al., 2014) menyatakan semakin tinggi self-efficacy yang dimiliki seorang auditor maka akan semakin baik pula judgment yang dikeluarkan nantinya oleh auditor itu sendiri.

Penelitian yang dilakukan oleh Wijaya (2012) menunjukkan self-efficacy berpengaruh positif terhadap audit judgment. Hasil Penelitian tersebut juga didukung oleh penelitian Pertiwi et al. (2015) menunjukkan hasil bahwa selfefficacy berpengaruh positif dan signifikan terhadap audit judgment, hal ini karena seorang individu dengan memiliki self-efficacy yang tinggi akan senantiasa lebih cenderung untuk mempertimbangkan, mengevaluasi dan menggabungkan kemampuan yang diketahuinya sebelum pada akhirnya dia menentukan suatu pilihan . Penelitian yang dilakukan oleh Nadhiroh (2010) menunjukkan hasil yang berbeda bahwa self-efficacy tidak berpengaruh secara signifikan terhadap kinerja auditor dalam pembuatan audit judgment. Fenomena tersebut kemungkinan lebih dipengaruhi imbalan yang diberikan atas kemampuannya, walaupun seseorang mempunyai self-efficacy yang tinggi, namun jika imbalan yang diberikan rendah maka self-efficacy yang dimiliki tidak akan berpengaruh terhadap kinerja auditor dalam pembuatan audit judgment.

Cognitive psychology dan marketing menyatakan bahwa gender sebagai faktor level individual dapat berpengaruh terhadap kinerja yang memerlukan judgment dalam berbagai kompleksitas tugas. Penelitian Chung \& Monroe (2001) menyatakan bahwa perempuan dapat lebih efisien dan efektif dalam memproses informasi dalam tugas yang kompleks dibanding laki-laki dikarenakan perempuan lebih memiliki kemampuan untuk membedakan dan mengintegrasikan kunci keputusan. Hasil penelitian Suardikha \& Budiarta (2017) menyatakan bahwa gender mampu memoderasi pengaruh self-efficacy pada audit judgment, sebaliknya gender tidak mampu memoderasi pengaruh kompleksitas tugas pada audit judgment. Dari hasil penelitian tersebut, maka peneliti tertarik memakai variabel gender sebagai variabel moderasi dan juga menambahkan variabel orientasi tujuan untuk dimoderasi oleh gender.

Ruegger \& King (1992) menyatakan wanita memiliki pertimbangan moral yang lebih tinggi dari pada seorang pria. Namun pada beberapa penelitian menunjukan bahwa gender tidak berpengaruh signifikan terhadap audit judgment. Hartanto (1999) menyatakan bahwa gender tidak berpengaruh secara signifikan terhadap audit judgment. Penelitian yang dilakukan oleh Trisnaningsih \& Isnawati (2004) menyatakan bahwa tidak ada perbedaan kinerja auditor dilihat dari segi gender.

Berdasarkan hasil penelitian terdahulu tidak konsisten, dapat diduga terdapat variabel kontingensi. Variabel tersebut memberi pengaruh memperkuat atau memperlemah pengaruh variabel orientasi tujuan dan self-efficacy pada audit judgement. Dugaan adanya variabel kontingensi inilah yang mendorong peneliti untuk menguji kembali pengaruh orientasi tujuan dan self-efficacy terhadap audit judgment dengan menambahkan gender sebagai variabel pemoderasi. 


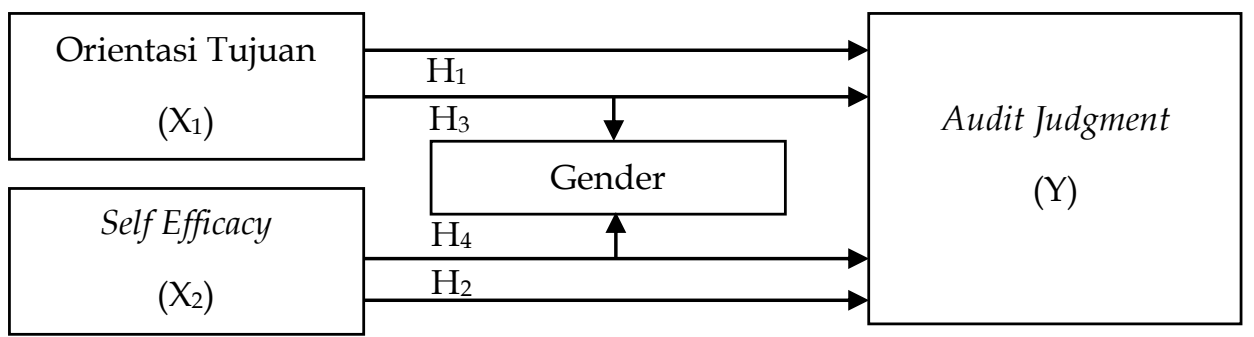

Gambar 1. Kerangka Penelitian

Sumber: Data Penelitian, 2020

Orientasi tujuan merupakan kerangka mental bagaimana individu menginterpretasi dan merespon situasi atau kejadian yang dihadapinya (Dweck \& Leggett, 1988). Berdasarkan teori human information processing saat memproses suatu informasi auditor memiliki orientasi tujuan yang tinggi maka audit judgment (output) yang diambil akan semakin akurat. Hal ini dikarenakan orientasi tujuan yang tinggi berfokus pada pengembangan kompetensi dengan menyerap keterampilan baru dan belajar dari pengalaman yang dimiliki oleh auditor dalam memproses informasi tersebut. Teori penetapan tujuan menegaskan bahwa tujuan yang lebih spesifik, sulit dan menantang akan menghasilkan kinerja yang lebih tinggi dan baik dibandingkan dengen tujuan yang tidak jelas, seperti tujuan yang mudah atau tidak ada tujuan sama sekali (Nadhiroh, 2010).

Hasil penelitian yang dilakukan Pertiwi et al., (2015), dan Trianevant (2014) menunjukkan bahwa orientasi tujuan berpengaruh positif terhadap audit judgment. Auditor yang memiliki orientasi tujuan tinggi berfokus pada pengembangan kompetensi dalam memproses informasi untuk menentukan suatu judgment, sehingga auditor yang memiliki tujuan yang lebih spesifik memiliki kinerja yang lebih baik dibandingkan dengan yang tidak memiliki tujuan yang jelas. Penelitian dilakukan oleh Nadhiroh (2010) menunjukan hasil yang berbeda dimana orientasi tujuan pembelajaran tidak berpengaruh secara signifikan terhadap pembuatan audit judgment.

$\mathrm{H}_{1}$ : Orientasi tujuan berpengaruh positif pada audit judgment.

Self-efficacy dapat diartikan sebagai rasa percaya diri seseorang dalam menjalankan sebuah tugas pada sebuah tingkat tertentu. Berdasarkan teori human information processing saat memproses informasi auditor memiliki self-efficacy yang tinggi maka audit judgment (output) yang diambil akan akurat. Hal ini dikarenakan auditor yang memiliki self-efficacy yang tinggi cenderung memilih tugas yang tingkat kesukarannya sesuai dengan kemampuannya, mampu menguasai beberapa bidang sekaligus untuk menyelesaikan tugas dan yakin terhadap tindakan yang dilakukan akan memberikan hasil yang diharapkan. Self-efficacy individu dapat dilihat dari tingkat (level), keluasan (generality), kekuatan (strenght). Individu yang memiliki self-efficacy yang tinggi cenderung memilih tugas yang tingkat kesukarannya sesuai dengan kemampuannya. Pada keluasan (generality), Auditor dapat memposisikan dirinya sebagai auditor yang memiliki self-efficacy tinggi jika auditor dapat memahami beberapa bidang sekaligus untuk menyelesaikan suatu tugas. Sebaliknya mereka yang belum mampu menyelesaikan berbagai bidang tugas sekaligus dikatagorikan sebagai auditor yang memiliki self-efficacy rendah. Pada kekuatan (strenght), self-efficacy yang tinggi 
menunjukan bahwa individu yakin terhadap tindakan yang dilakukan akan memberikan hasil yang diharapkan

Self-efficacy menjadi indikator dasar melakukan usaha yang keras, bahkan ketika menemui hambatan sekalipun. Hal ini sesuai dengan penelitian Iskandar \& Sanusi (2011), Shanti (2019), Suardikha \& Budiarta (2017), Suwandi et al. (2017), Trianevant (2014), dan Tumurang et al. (2019) dimana auditor yang memiliki selfefficacy tinggi menunjukkan penilaian audit yang lebih baik daripada auditor dengan self-efficacy rendah. Self-efficacy yang tinggi menunjukan kepercayaan diri seseorang atas kemampuannya dalam menyelesaikan pekerjaan audit maka akan semakin baik audit judgment yang diambil oleh auditor.

$\mathrm{H}_{2}$ : Self-efficacy berpengaruh positif pada audit judgment.

Meyers-Levy (1986) mengembangkan kerangka teoritis untuk menjelaskan kajian tentang perbedaan antara perempuan dan laki laki dalam memproses informasi. Kerangka teoritis ini mereka sebut dengan "selectivity hypothesis". Perbedaaan yang didasarkan pada isu gender dalam pemrosesan informasi dan pembuatan keputusan didasarkan atas pendekatan yang berbeda yaitu bahwa laki-laki dan perempuan menggunakan pemrosesan inti informasi dalam memecahkan masalah dan membuat inti keputusan.

Berdasarkan teori human information processing saat auditor memproses suatu informasi maka audit judgment (output) yang diambil akan semakin akurat. Hal ini dikarenakan orientasi tujuan yang tinggi berfokus pada pengembangan kompetensi dengan menyerap keterampilan baru dan belajar dari pengalaman yang dimiliki oleh auditor dalam memproses informasi tersebut. Saat dihadapkan dengan orientasi tujuan auditor dapat memberikan respon yang berbeda-beda baik laki-laki ataupun perempuan. Auditor perempuan cenderung akan lebih teliti dan tidak tergesa-gesa dalam mengolah informasi yang didapatnya.

$\mathrm{H}_{3}$ : Gender memoderasi pengaruh orientasi tujuan pada audit judgment.

Meyers-Levy (1986) mengembangkan kerangka teoritis untuk menjelaskan kajian tentang perbedaan antara perempuan dan laki laki dalam memproses informasi. Kerangka teoritis ini mereka sebut dengan "selectivity hypothesis". Perbedaaan yang didasarkan pada isu gender dalam pemrosesan informasi dan pembuatan keputusan didasarkan atas pendekatan yang berbeda yaitu bahwa laki-laki dan perempuan menggunakan pemrosesan inti informasi dalam memecahkan masalah dan membuat inti keputusan.

Berdasarkan teori human information processing saat memproses informasi auditor memiliki self-efficacy yang tinggi maka audit judgment (output) yang diambil akan akurat. Hal ini dikarenakan auditor yang memiliki self-efficacy yang tinggi cenderung memilih tugas yang tingkat kesukarannya sesuai dengan kemampuannya, mampu menguasai beberapa bidang sekaligus untuk menyelesaikan tugas dan yakin terhadap tindakan yang dilakukan akan memberikan hasil yang diharapkan.

Perempuan pada umumnya memiliki tingkat pertimbangan moral yang lebih tinggi daripada laki-laki, sehingga membuat adanya perbedaan persepsi etika pada saat proses pengambilan keputusan. Vinciguerra (2001) mengindikasikan bahwa pertimbangan moral dan alasan mendasar dalam etika pada laki-laki dan perempuan berbeda, perempuan memiliki pertimbangan moral yang lebih tinggi dibandingkan dengan laki-laki. Pertimbangan moral yang 
berbeda antara perempuan dan laki-laki diduga dapat mempengaruhi kepercayaan seseorang dalam menjalankan sebuah tugas pada sebuah tingkat, yang mempengaruhi aktifitas pribadi terhadap pencapaian tujuan. Hasil penelitian Suardikha \& Budiarta (2017) menunjukan bahwa gender mampu memoderasi pengaruh self-efficacy pada audit judgement.

$\mathrm{H}_{4}$ : Gender memoderasi pengaruh self-efficacy pada audit judgment.

\section{METODE PENELITIAN}

Desain penelitian ini menggunakan pendekatan kuantitatif yang berbentuk asosiatif. Penelitian ini mengambil lokasi Kantor Akuntan Publik wilayah Provinsi Bali. Kantor Akuntan Publik adalah suatu bentuk organisasi akuntan publik yang memperoleh izin sesuai dengan peraturan perundang-undangan yang berusaha di bidang pemberian jasa profesional dalam praktik akuntan publik. Objek penelitian ini adalah meneliti audit judgment di seluruh Kantor Akuntan Publik yang berlokasi di Provinsi Bali. Populasi dari penelitian ini adalah seluruh auditor yang bekerja pada KAP di wilayah Bali yang terdaftar dalam IAPI 2020 sebanyak 110 orang. Teknik penentuan sampel yang digunakan dalam penelitian ini adalah dengan teknik purposive sampling. Metode pengumpulan data dilakukan dengan metode survey dengan teknik pengumpulan data melalui teknik kuesioner. Teknik analisis data yang digunakan dalam penelitian ini adalah teknik analisis regresi moderasi atau Moderated Regression Analysis (MRA) dengan pendekatan interaksi.

$Y=\alpha+\beta_{1} X_{1}+\beta_{2} X_{2}+\beta_{3} X_{3}+\varepsilon+\beta_{X 1 \_} X_{3} X_{1} . X_{3}+\beta_{X_{2} X_{3}} X_{2} . X_{3}$

\section{HASIL DAN PEMBAHASAN}

Berdasarkan karakteristik responden pada penelitian ini pada indicator jenis kelamin mayoritas responden adalah perempuan 59,7 persen dan laki-laki dengan jumlah presentase 40,3 persen. Berdasarkan kategori umur, mayoritas responden berumur $20 \mathrm{~s} / \mathrm{d} 30$ tahun dengan jumlah presentase 85,1 persen dan mayoritas jenjang pendidikan S1 dengan jumlah presentase 70,2 persen. Dari 67 responden 68,7 persen berkedudukan sebagai auditor junior dan 31,3 persen responden berkedudukan sebagai auditor senior. Berdasarkan kategori lamanya bekerja, yang mendominasi adalah responden dengan lama bekerja $1 \mathrm{~s} / \mathrm{d} 2$ tahun sebanyak 52,2 persen diikuti dengan lama bekerja $3 \mathrm{~s} / \mathrm{d} 5$ tahun sebanyak 25,4 persen.

Tabel 1. Hasil Statistik Deskriptif

\begin{tabular}{lccccc}
\hline Variabel & $\mathrm{N}$ & Minimum & Maximum & Mean & Std. Deviation \\
\hline Orientasi Tujuan & 67 & 18,000 & 40,000 & 32,836 & 7,743 \\
Self-Efficacy & 67 & 9,000 & 20,000 & 16,358 & 3,930 \\
Gender & 67 & 0,000 & 1,000 & 0,403 & 0,494 \\
Audit Judgment & 67 & 13,000 & 30,000 & 24,597 & 6,066 \\
\hline
\end{tabular}

Sumber: Data Penelitian, 2020

Berdasarkan Tabel 1, dapat diketahui bahwa banyaknya kuesioner yang diolah adalah 67 kuesioner untuk masing-masing variabel. Variabel audit judgment $(\mathrm{Y})$ memiliki nilai minimum sebesar 13, nilai maksimum sebesar 30, mean sebesar 24,597 dan standar deviasi sebesar 6,066 Ini berarti bahwa terjadi perbedaan nilai audit judgment yang diteliti terhadap nilai rata-ratanya sebesar 6,066 . Variabel orientasi tujuan $\left(X_{1}\right)$ memiliki nilai minimum sebesar 18 , nilai 
maksimum sebesar 40, mean sebesar 32,836 dan standar deviasi sebesar 7,743. Ini berarti bahwa terjadi perbedaan nilai orientasi tujuan yang diteliti terhadap nilai rata-ratanya sebesar 7,743. Variabel self-efficacy $\left(X_{2}\right)$ memiliki nilai minimum sebesar 9, nilai maksimum sebesar 20, mean sebesar 16,3582 dan standar deviasi sebesar 3,930. Ini berarti bahwa terjadi perbedaan nilai self-efficacy yang diteliti terhadap nilai rata-ratanya sebesar 3,930. Variabel gender memiliki nilai minimum sebesar 0, nilai maksimum sebesar 1, mean sebesar 0,403 dan standar deviasi sebesar 0,494. Ini berarti bahwa terjadi perbedaan nilai gender yang diteliti terhadap nilai rata-ratanya sebesar 0,494.

Syarat suatu model regresi dapat dianalisis menggunakan teknik analisis regresi linear berganda adalah terbebas dari masalah normalitas, multikolinearitas dan heteroskedastisitas. Hasil uji normalitas menunjukkan bahwa nilai Kolmogorov Smirnov sebesar 0,087 sedangkan nilai Asymp. Sig. (2-tailed) sebesar 0,102. Hasil ini mengindikasikan bahwa model persamaan regresi tersebut berdistribusi normal karena nilai Asymp. Sig. (2-tailed) 0,102 lebih besar dari nilai 0,05. Hasil uji multikolinearitas menunjukkan bahwa nilai tolerance untuk setiap variabel lebih besar dari 0,10 dan nilai VIF lebih kecil dari 10 yang berarti model persamaan regresi bebas dari multikolinearitas. Uji heteroskedastisitas bertujuan menguji apakah dalam model regresi terjadi ketidaksamaan variance dari residual satu pengamatan ke pengamatan lain. Uji heteroskedastisitas pada penelitian ini menggunakan uji statistik dengan menggunakan uji glejser. Uji glejser dilakukan dengan cara meregresi nilai absolute residual dari model yang diestimasi terhadap variabel independen. Jika nilai tingkat signifikasi berada di atas 0,05 maka model regresi ini bebas dari masalah heteroskedastisitas. Nilai signifikasi masing-masing variabel nilainya melebihi 0,05 . Hal ini menunjukkan bahwa model regresi bebas dari gejala heteroskedastisitas,

Tabel 2. Hasil Moderated Regression Analysis

\begin{tabular}{|c|c|c|c|c|c|}
\hline \multirow[t]{2}{*}{ Variabel } & \multicolumn{2}{|c|}{$\begin{array}{l}\text { Unstandardized } \\
\text { Coefficient }\end{array}$} & \multirow{2}{*}{$\begin{array}{c}\text { Standardized } \\
\text { Coefficient }\end{array}$} & \multirow[t]{2}{*}{$\mathrm{t}$} & \multirow[t]{2}{*}{ Sig. } \\
\hline & B & Std. Error & & & \\
\hline Constant & 0,040 & 1,367 & & 0,029 & 0,977 \\
\hline $\mathrm{X}_{1}$ & 0,388 & 0,061 & 0,513 & 6,393 & 0,000 \\
\hline$X_{2}$ & 0,724 & 0,127 & 0,454 & 5,692 & 0,000 \\
\hline$X_{3}$ & $-1,076$ & 2,512 & $-0,096$ & $-0,428$ & 0,670 \\
\hline $\mathrm{X}_{1} \mathrm{X}_{3}$ & 0,345 & 0,103 & 0,782 & 3,365 & 0,001 \\
\hline $\mathrm{X}_{2} \mathrm{X}_{3}$ & $-0,645$ & 0,217 & $-0,737$ & $-2,969$ & 0,004 \\
\hline \multicolumn{6}{|c|}{ Adjusted $R_{\text {square }}: 0,819$} \\
\hline Fhitung & $: 60,741$ & & & & \\
\hline Sig. Fhitung & $: 0,000$ & & & & \\
\hline
\end{tabular}

Sumber: Data Penelitian, 2020

Berdasarkan Tabel 2, diperoleh persamaan regresi linear berganda sebagai berikut.

$$
\hat{Y}=0,040+0,388 X_{1}+0,724 X_{2}-1,076 X_{3}+0,345 X_{1} \cdot X_{3}-0,645 X_{2} \cdot X_{3}
$$

Koefisien determinasi yang digunakan pada analysis regresi moderasi adalah nilai Adjusted $\mathrm{R}_{\text {square. Nilai Adjusted }} \mathrm{R}_{\text {square }}$ nilai koefisien determinasi menunjukkan seberapa jauh kemampuan variabel independen dalam menerangkan variasi variabel dependen. Berdasarkan Tabel 2, dapat dilihat besarnya nilai koefisien determinasi sebesar 0,819 atau 81,9 persen. Hal ini berarti 
bahwa variabel audit judgment dapat dijelaskan oleh variabel orientasi tujuan, selfefficacy dan gender sebagai pemoderasi sebesar 81,9 persen sedangkan 18,1 persen sisanya dijelaskan oleh faktor lain yang tidak diuji dalam penelitian ini.

Orientasi tujuan berpengaruh positif terhadap audit judgment. Semakin tinggi orientasi tujuan auditor maka semakin akurat juga audit judgment yang dibuat oleh auditor. Berdasarkan teori human information processing saat auditor memproses suatu informasi maka audit judgment (output) yang diambil akan semakin akurat. Hal ini dikarenakan orientasi tujuan yang tinggi berfokus pada pengembangan kompetensi dengan menyerap keterampilan baru dan belajar dari pengalaman yang dimiliki oleh auditor dalam memproses informasi tersebut. Teori penetapan tujuan menegaskan bahwa tujuan yang lebih spesifik, sulit dan menantang akan menghasilkan kinerja yang lebih tinggi dan baik dibandingkan dengen tujuan yang tidak jelas, seperti tujuan yang mudah atau tidak ada tujuan sama sekali (Nadhiroh, 2010).

Hasil penelitian ini konsisten dengan penelitian yang dilakukan Pertiwi et al. (2015) dan Trianevant (2014) menunjukkan bahwa orientasi tujuan berpengaruh positif terhadap audit judgment. Auditor yang memiliki orientasi tujuan tinggi berfokus pada pengembangan kompetensi dalam memproses informasi untuk menentukan suatu judgment, sehingga auditor yang memiliki tujuan yang lebih spesifik memiliki kinerja yang lebih baik dibandingkan dengan yang tidak memiliki tujuan yang jelas.

Self-efficacy berpengaruh positif terhadap audit judgment. Semakin tinggi selfefficacy auditor maka semakin akurat juga audit judgment yang dibuat oleh auditor. Self-efficacy dapat diartikan sebagai rasa percaya diri seseorang dalam menjalankan sebuah tugas pada sebuah tingkat tertentu. Berdasarkan teori human information processing saat memproses informasi auditor memiliki self-efficacy yang tinggi maka audit judgment (output) yang diambil akan akurat. Hal ini dikarenakan auditor yang memiliki self-efficacy yang tinggi cenderung memilih tugas yang tingkat kesukarannya sesuai dengan kemampuannya, mampu menguasai beberapa bidang sekaligus untuk menyelesaikan tugas dan yakin terhadap tindakan yang dilakukan akan memberikan hasil yang diharapkan.

Self-efficacy individu dapat dilihat dari tingkat (level), keluasan (generality), kekuatan (strenght). Pada tingkat (level), individu yang memiliki self-efficacy yang tinggi cenderung memilih tugas yang tingkat kesukarannya sesuai dengan kemampuannya. Pada keluasan (generality), Auditor dapat memposisikan dirinya sebagai auditor yang memiliki self-efficacy tinggi jika auditor dapat memahami beberapa bidang sekaligus untuk menyelesaikan suatu tugas. Sebaliknya mereka yang belum mampu menyelesaikan berbagai bidang tugas sekaligus dikatagorikan sebagai auditor yang memiliki self-efficacy rendah. Pada kekuatan (strenght), self-efficacy yang tinggi menunjukan bahwa individu yakin terhadap tindakan yang dilakukan akan memberikan hasil yang diharapkan (Sanusi et al., 2007).

Self-efficacy menjadi indikator dasar melakukan usaha yang keras, bahkan ketika menemui hambatan sekalipun. Hal ini sesuai dengan penelitian Sanusi dan Iskandar \& Sanusi (2011), Shanti (2019), Suardikha \& Budiarta (2017), Suwandi et al. (2017), Trianevant (2014), dan Tumurang et al. (2019) dimana auditor yang memiliki self-efficacy tinggi menunjukkan penilaian audit yang lebih baik daripada 
auditor dengan self-efficacy rendah. Self-efficacy yang tinggi menunjukan kepercayaan diri seseorang atas kemampuannya dalam menyelesaikan pekerjaan audit maka akan semakin baik audit judgment yang diambil oleh auditor.

Gender memperkuat pengaruh orientasi tujuan pada audit judgment. Pertimbangan moral yang berbeda antara perempuan dan laki-laki dapat memperkuat pengaruh orientasi tujuan pada audit judgment. Perempuan pada umumnya memiliki tingkat pertimbangan moral yang lebih tinggi daripada lakilaki, sehingga membuat adanya perbedaan persepsi etika pada saat proses pengambilan keputusan. Vinciguerra (2001) mengindikasikan bahwa pertimbangan moral dan alasan mendasar dalam etika pada laki-laki dan perempuan berbeda, perempuan memiliki pertimbangan moral yang lebih tinggi dibandingkan dengan laki-laki. Pertimbangan moral yang berbeda antara perempuan dan laki-laki diduga dapat mempengaruhi kepercayaan seseorang dalam menjalankan sebuah tugas pada sebuah tingkat, yang mempengaruhi aktifitas pribadi terhadap pencapaian tujuan. Pertimbangan moral yang berbeda antara perempuan dan laki-laki memberikan motivasi untuk mengembangkan kompetensi dengan menyerap keterampilan baru dan belajar dari pengalaman yang dimiliki oleh auditor.

Gender memperlemah pengaruh self-efficacy pada audit judgment. Pertimbangan moral yang berbeda antara perempuan dan laki-laki dapat memperlemah pengaruh self-efficacy pada audit judgment. Perempuan pada umumnya memiliki tingkat pertimbangan moral yang lebih tinggi daripada lakilaki, sehingga membuat adanya perbedaan persepsi etika pada saat proses pengambilan keputusan. Vinciguerra (2001) mengindikasikan bahwa pertimbangan moral dan alasan mendasar dalam etika pada laki-laki dan perempuan berbeda, perempuan memiliki pertimbangan moral yang lebih tinggi dibandingkan dengan laki-laki. Pertimbangan moral yang berbeda antara perempuan dan laki-laki diduga dapat mempengaruhi kepercayaan seseorang dalam menjalankan sebuah tugas pada sebuah tingkat, yang mempengaruhi aktifitas pribadi terhadap pencapaian tujuan. Pertimbangan moral yang berbeda antara perempuan dan laki-laki memperlemah rasa percaya diri seseorang dalam menjalankan sebuah tugas.

\section{SIMPULAN}

Berdasarkan pembahasan pada latar belakang, landasan teori, metodelogi penelitian dan hasil penelitian, maka dapat diambil simpulan yakni orientasi tujuan berpengaruh positif pada audit judgment. Semakin tinggi orientasi tujuan seorang auditor maka audit judgment yang akan diambil semakin akurat. Selfefficacy berpengaruh positif pada audit judgment. Semakin tinggi self-efficacy seorang auditor maka semakin akurat audit judgment yang dibuat oleh auditor. Gender memperkuat pengaruh orientasi tujuan pada audit judgment. Gender memperlemah pengaruh self-efficacy pada audit judgment.

Berdasarkan pembahasan dan simpulan yang telah disampaikan, maka saran yang dapat diberikan yakni auditor yang melakukan audit diharapkan memiliki orientasi tujuan yang jelas. Auditor dapat meningkatkan orientasi tujuan dengan mencari kesempatan mengembangkan keterampilan dan pengetahuan baru. Manajemen KAP perlu melakukan dan memfasilitasi forum diskusi bersama 
antar auditor senior dengan auditor junior untuk sharing pengetahuan dan pengalaman (khususnya audit lapangan) yang mereka miliki seperti diskusi terfokus dari suatu group (Focus Group Discussion / FGD). Adanya forum diskusi dapat mengingkatkan audit judgment, auditor senantiasa belajar dari pengalaman auditor yang lebih senior atau pada auditor yang lebih berpengalaman. Auditor diharapkan meningkatkan kemampuan analisisnya sehingga dapat membuat audit judgment yang baik pada saat menghadapi tugas yang kompleks. Manajemen KAP perlu memberikan penugasan audit lapangan yang lebih banyak dan variatif dalam rangka lebih membiasakan auditor membuat audit judgment dari berbagai kasus dan laporan keuangan kliennya. Adanya tugas yang lebih bervariatif mengasah kemampuan analisis seorang auditor sehingga auditor diharapkan memiliki self-efficacy yang tinggi pada saat menghadapi tugas audit.

\section{REFERENSI}

Ariyantini, K. E., Sujana, E., \& Darmawan., N. A. S. (2014). Pengaruh Pengalaman Auditor, Tekanan Ketaatan dan Kompleksitas Tugas Terhadap Audit Judgment (Studi Empiris Pada BPKP Perwakilan Provinsi Bali). Jurnal Akuntansi Dan Keuangan, 2(1), 7-20.

Ariyanto, D., Firdaus, G. M., Sari, M. M. R., Dewi, A. A., \& Made Gilang Jhuniantara, I. (2020). How self control and situational pressure influence the tendency to receive gratification: An experimental study. International Journal of Criminology and Sociology, 9, 400-414. https://doi.org/10.6000/19294409.2020.09.39

Bandura, A. (1993). Perceived Self-Efficacy in Cognitive Development and Functioning. Educational Psychologist, 28(2), 117-148. https://doi.org/10.1207/s15326985ep2802_3

Candraningrat, I. R., Abundanti, N., Mujiati, N. W., Erlangga, R., \& Jhuniantara, I. M. G. (2021). The role of financial technology on development of MSMEs. Accounting, 7(1), 225-230. https:// doi.org/10.5267/j.ac.2020.9.014

Chung, J., \& Monroe, G. S. (2001). A Research Note on the Effects of Gender and Task Complexity on an Audit Judgment. Behavioral Research in Accounting, 13(1), 111-125. https:// doi.org/10.2308/bria.2001.13.1.111

Darlis, E., Sari, R. N., \& Febrianti, I. (2014). Pengaruh Pengetahuan Terhadap Audit Judgement dengan Kompleksitas Tugas dan Independensi Sebagai Variabel Moderating (Studi Pada Akuntan Publik di KAP Wilayah Sumatera).

Dweck, C. S., \& Leggett, E. L. (1988). A Social-Cognitive Approach to Motivation and Personality. Psychological Review, 95(2), 256-273. https:/ / doi.org/10.1037/0033-295X.95.2.256

Hartanto, S. Y. (1999). Analisis Pengaruh tekanan Ketaatan Terhadap Judgment Auditor. Universitas Gadjah Mada.

Irwanti, A. N. (2011). Pengaruh Gender dan Tekanan Ketaatan Terhadap Audit judgment, Kompleksitas Tugas sebagai Variabel Moderating. Universitas Diponegoro.

Iskandar, T. M., \& Sanusi, Z. M. (2011). Assessing the effects of self-efficacy and task complexity on internal control audit judgment. Asian Academy of Management Journal of Accounting and Finance, 7(1), 29-52.

Meyers-Levy, J. (1986). Gender differences in information processing: A selectivity 
interpretation. Northwestern University.

Nadhiroh, S. A. (2010). Pengaruh Kompleksitas Tugas, Orientasi Tujuan, dan Selfefficacy terhadap Kinerja Auditor dalam Pembuatan Audit judgment (Studi Pada Kantor Akuntan Publik di Semarang). Universitas Diponegoro, Semarang.

Nugraha, M. (2014). Pengaruh Profesionalisme Terhadap Audit judgment Auditor Internal Pada Satuan Pengawas Internal Perguruan Tinggi Negeri Yogyakarta dan Surakarta Dengan Menggunakan Konflik Peran Sebagai Variabel Moderasi. Universitas Negeri Yogyakarta, Yogyakarta.

Pertiwi, S. E., Gumawan, H., \& Purnamasari, P. (2015). Pengaruh Orientasi Tujuan dan Self-Efficacy Terhadap Audit Judgment. Prosiding Penelitian Sivitas Akademika, 244-253.

Praditaningrum, A. S., \& Januarti, I. (2012). Analisis Faktor-Faktor Yang Berpengaruh Terhadap Audit Judgment (Studi Pada BPK RI Perwakilan Provinsi Jawa Tengah). Universitas Diponegoro Semarang.

Puspitasari, R. (2011). Analisis Pengaruh Gender, Tekanan Ketaatan, Kompleksitas Tugas, dan Pengalaman terhadap Kinerja Auditor dalam Pembuatan Audit Judgment. Universitas Diponogoro Semarang.

Ruegger, D., \& King, E. W. (1992). A study of the effect of age and gender upon student business ethics. Journal of Business Ethics, 11(3), 179-186. https://doi.org/10.1007/BF00871965

Sanusi, Z. M., Iskandar, T. M., \& Poon, J. M. L. (2007). Effects of Goal Orientation and Task Complexity on Audit Judgment Performance. Malaysian Accounting Review, 6(2), 123-139.

Shanti, Y. K. (2019). Pengaruh Self Efficacy Terhadap Audit Judgement Dengan Senioritas Auditor Sebagai Pemoderasi (Studi Kasus pada Inspektorat Kota Bogor dan Depok). Jurnal Akuntansi Barelang, 3(2), 115-124. https://doi.org/10.33884/jab.v3i2.1237

Suardikha, I. M. S., \& Budiarta, K. (2017). Kemampuan Gender Memoderasi Pengaruh Self-Efficacy Dan Kompleksitas Tugas Pada Audit Judgment. Jurnal Ekonomi Dan Pariwisata, 12(1), 107-121.

Suwandi, Zulbahridar, \& Ilham, E. (2017). Pengaruh self efficacy, kecerdasan emosional, tekanan ketaatan dan kompleksitas tugas terhadap audit judgment auditor. E-Jurnal Akuntansi Universitas Riau, 2(1), 11.

Trianevant, M. (2014). Pengaruh Gender, Orientasi Tujuan, Self-efficacy, dan Pengalaman terhadap audit judgment. (Survei pada 11 Kantor Akuntan Publik di Jakarta). Universitas Widyatama.

Trisnaningsih, S., \& Isnawati, S. (2004). Perbedaan kinerja auditor dilihat dari segi gender. The Indonesian Journal of Accunting Research, 7(1). https://doi.org/10.33312/ijar.113

Tumurang, D. O., Ilat, V., \& Kalalo, M. Y. B. (2019). Pengaruh Self Efficacy, Kompleksitas Tugas Dan Keahlian Audit Terhadap Audit Judgment Auditor Pada Inspektorat Provinsi Sulawesi Utara. Jurnal EMBA: Jurnal Riset Ekonomi, Manajemen, Bisnis Dan Akuntansi, 7(3), 3919-3928. https://doi.org/10.35794/emba.v7i3.24906

Vinciguerra, B. M. (2001). Auditor independence: An examination of the effect of self -interest threats and organizational safeguards on auditor judgment. In ProQuest Dissertations and Theses. 
Wijaya, Y. (2012). Pengaruh Pengetahuan, Self-efficacy, Orientasi Etika, Orientasi Tujuan, dan Kompleksitas Tugas terhadap Audit judgment (Studi Empiris pada Kantor Akuntan Publik di Semarang). Universitas Katolik Soegijapranata.

Wijayantini, K. A. S., Yuniarta, G. A., \& Atmadja, A. (2014). Pengaruh Tekanan Ketaatan , Kompleksitas Tugas, Dan Self-Efficacy Terhadap Audit Judgement (Studi Empiris Pada Kantor Akuntan Publik Di Bali). E-Journal S1 Ak Universitas Pendidikan Ganesha, 2(1), 1-9.

Wijayatri, A. (2010). Pengaruh Tekanan Ketaatan, Kompleksitas Tugas dan Keahlian Audit Terhadap Audit judgment (Studi Empiris Pada Kantor Akuntan Publik di Surabaya). Universitas Pembangunan Nasional. 